Relations industrielles

Industrial Relations

\title{
Ghilarducci, Teresa, Labor's Capital. The Economics and Politics of Private Pensions
}

\section{Douglas A. Smith}

Volume 48, numéro 1, 1993

URI : https://id.erudit.org/iderudit/050846ar

DOI : https://doi.org/10.7202/050846ar

Aller au sommaire du numéro

Éditeur(s)

Département des relations industrielles de l'Université Laval

ISSN

0034-379X (imprimé)

1703-8138 (numérique)

Découvrir la revue

Citer ce compte rendu

Smith, D. A. (1993). Compte rendu de [Ghilarducci, Teresa, Labor's Capital. The Economics and Politics of Private Pensions]. Relations industrielles / Industrial Relations, 48(1), 206-207. https://doi.org/10.7202/050846ar

Tous droits réservés (C) Département des relations industrielles de l'Université Laval, 1993
Ce document est protégé par la loi sur le droit d'auteur. L’utilisation des services d'Érudit (y compris la reproduction) est assujettie à sa politique d'utilisation que vous pouvez consulter en ligne.

https://apropos.erudit.org/fr/usagers/politique-dutilisation/ 


\section{Labor's Capital - The Economics and Politics of Private Pensions, by Teresa} GHILARDuCCI, Cambridge, Mass., MIT Press, 1992, 213 p., ISBN 0-262-07139-8

This book provides an assessment of the system of private pensions in the United States including issues of interaction with the public Social Security system. The primary focus of the study is on reforming a system that is criticized because it is regressive, prone to employer manipulation of both the fate of the insured and the invested funds, limited in its coverage and inadequately understood even by members of plans.

There is an important union focus to this book which devotes an entire chapter to the role of trade unions in the existing system of private pensions. This focus is consistent with the results of both Canadian and U.S. research which show that membership in a trade union and firm size are the two most important factors in determining whether workers are covered by a pension plan. The Canadian debate between labour and management over the ownership of pension surpluses is pursued as an issue in the book but without reference to the substantial Canadian experience.

In fact, Canada and the U.S. are broadly similar with respect to pension coverage and pension systems. Roughly $75 \%$ of Canadian workers covered by collective agreements are also members of an employer pension plan. This contrasts with a coverage rate of approximately $20 \%$ for workers not covered by collective agreements. Overall, fewer than $50 \%$ of employed Canadians are members of pension plans and this ratio has declined somewhat in the last decade following a long period of historical increase. Only $10 \%$ of employees in firms with less than twenty employees are covered by employer pension plans in contrast with more than $70 \%$ of employees in firms with 500 or more employees.

Ghilarducci provides an extensive review of the economics literature on employer pensions. This review includes issues of moral hazard associated with the employer acting as insurer, various corporate finance aspects of pension administration and an anal$y$ sis of the factors that generate long-term pension agreements between firms and workers.

Most of the focus of this study is on defined-benefit pension plans. Historically, these plans that provide pension benefits according to a formula based usually on earnings in the last five years of employment have dominated the pension scene. For a variety of reasons including a growing regulatory burden for defined-benefit plans, there has been substantial recent growth in defined-contribution plans. These plans specify contribution levels and the ultimate benefit is determined by the assets held in the plan for each individual at the date of retirement. Plans of this kind are basically individual retirement accounts administered through the place of employment.

Ghilarducci recognizes that many of the problems that she analyzes such as employer manipulation of pension assets are specific to defined-benefit plans. The results of many Canadian employee surveys confirm Ghilarducci's contention that most workers prefer defined-benefit plans in spite of the problems associated with them. This may be a genuine limitation of pension reform initiatives that rely on greater use of defined-contribution plans.

The regressiveness of the existing system of employer pensions is a dominant theme in this volume and not much in the way of data should be required to convince 
most readers of this point. Higher wage workers are more likely to be covered by employer plans and workers who become unemployed or change jobs frequently build up few entitlements in defined-benefit plans. As a result, the distribution of retirement income is much more skewed than the distribution of income from employment.

In Canada, the Canada Pension Plan is intended to provide a floor of income support for retired workers. Other means-tested programs provide a supplement. Private pension plans and Registered Retirement Savings Plans round out this system. In general terms, this is similar to the U.S. system. The problems of the U.S system with regard to coverage, adequacy and the other problem areas identified by Ghilarducci are largely shared by the Canadian system.

Ghilarducci's proposed reforms for this system are radical. She would replace all private pensions with a "democratized" universal public system. The generally interventionist flavour of most of this book is shown by her proposal to use the funds accumulated in such a system as "a means to finance a national industrial policy" (p. 175). The problems with the existing pension system are well-documented in this book but this is less true for the solutions.

Douglas A. SMITH

Carleton University

From Middle Income to Poor: Downward Mobility among Displaced Steelworkers, by Allison ZrPPaY, New York, Praeger Book News, 1991, 144 p., ISBN 0-275-93791-7

Allison Zippay has written an insightful and useful sociological study about the officially unmourned victims of the precipitous industrial decline of the U.S. "Unmourned" because in the 1980 's, the nation's leadership and media generally portrayed the industrial collapse of what had been the world's leading producing nation as an insignificant subplot to the surface glitter and self-preoccupation of the Reagan years. While the President (amplified by a chorus of national and local "opinion makers") proclaimed that the transition to a postindustrial, service economy was a great economic advance, the media, by and large, unable to decide whether the demise of the mills was to be mourned or celebrated, proclaimed events inevitable and passed guickly on with barely a sideways glance at the tragic consequences of a nation's failed labor and industrial policy.

The "tragic consequences" are the subject of Zippay's book, which studies a slice of one hundred workers at two plants in the Shenango Valley on Pennsylvania's Western border with Ohio. The largest town in the area is Sharon, $\mathrm{Pa}$. not far from Youngstown, Ohio, where some of the most vocal and organized local resistance to Washington's laissez-faire economic policies of the 1980's was mounted. The book does not present a journalistic reconstruction of events, nor an economic analysis of their causes, but rather takes a cross-sectional survey of a group of dislocated industrial workers in a "run of the mill", "rust-belt" town, describes their plight and makes a pointed but limited attempt to explain the significance of their fate. 